AGRARIS: Journal of Agribusiness and Rural Development Research

Vol. 3 No.2 Juli 2017

\section{Rice Farming Performance for Sustainable Agriculture and Food Security in West Kalimantan}

https://doi.org/10.18196/agr.3248

\section{ABSTRACT}

For more than three decades, domestic rice production was not able to meet its growing demand and showed in poor performance. This research aims to analyze the performance of rice farming in West Kalimantan. The research was conducted using descriptive methods through interviews. The data was analyzed to describe farmer personal character, skill and knowlwdge, risk analysis, and technical efficiency employing stochastic frontier model. This study proved that farmer had 3 to 6 years of pupilage attainment; used rainfed; widely used Ciherang seeds; most of them had $0.25-1.25$ ha; only $20 \%$ of rice farming could achieve over 6.5 tons/ha. The distribution of technical efficiency showed that only $17.41 \%$ of rice farmer is able to achieve sufficient; while $60-70 \%$ of technical efficiency is achieved by $30.37 \%$ of rice farmer. However, the risk of production, prices, and income each was than 0.5 .

Keywords: farming performance, rice farmers, risk analysis, technical efficiency.

\section{INTRODUCTION}

Rice is one of the necessary strategic food for more than 90 percent of Indonesian. In addition, it's al so a strategic political commodity since the early of independence so that Indonesia has tried enormous to extend rice production. H owever, for more than three decades, domestic rice production wasn't able to meet its growing demand that proved by increasing of rice import from other countries. This condition was created worse harassed from the growth of palm oil plantation, particularly in W est Kalimantan and low rice productivity.

Rice productivity in W est Kalimantan in linewith data Statistics Indonesia in 2013 showed 3.184 tons/ ha and contributed 2 percent of domestic production. H owever, there have been still several ricewas imported, from Java through inter-island trade and there have been $13.69 \%$ per annum of rice unloading at PT. Pelindo. Thus, there's a possiblechance to extend rice production in West Kalimantan, both amount and quality. Furthermore, in recent years, there have been many programs issued by government to implement sustainable development of rice. H owever, these efforts haven't successful yet.

Several researches further as recent surveys in Indonesia have also shown a considerably lower performance of farm management. This is often because of farmers lacking the management skills to manage their farming systems properly. Consequences include reductions in crop yields and a waste of some natural resources. To enhance farm performance, it's necessary not solely to promote the implementation of farming programming strategies, however also improving system designs and performance and upgrading farmers' skills to control and manage their farming system more efficient.

Theon-farm performance, highly depends on farmers' management abilitys for usually no provision is created for adopting systems to the local operating conditions or to the farmers' technical skill for managing their systems. Any problems also need to dig deeper by using farm production performance data, either alone or in combination with financial data. Then, the next step is to diagnose the specific cause(s) that should be followed by efforts to find alternative solutions. The most promising solutions should be evaluated by develop- 
ing budgets to find the impacts on profitability and on cash flow. For major changes, developing an implementation plan is needed to go with these changes and continue monitoring farm performance to see if these changes are working as intended.

The used of data performance assessments are crucial for the farmers because it can hel p farmers to plan for the longterm staffing and worker development that by considering thethree Ps-productivity (what was done), personal traits (how it was done, conduct) and proficiency (skill) (Billikopf, 2014). The data performance assessments can also use to raise the wages or other rewards, to set up a coaching session and disciplinaryprocedures.

The benefit of performance data also in line with (Elferink, Kuneman, Visser, \& Van Der Wal, 2012) that also allowed farmers to compare and track their performance to others in the same region over the years. The performance data also give more comprehension for farmers to understand of various practice impacts and adapt over time for sustainability and mitigate those impacts. Food companies could assess the performance of their supply base (farmers) and extensive benchmark of sourcing agricultural products over the years for own or other food companies in the same region.

H owever, farmers need carefully to strike the right balance between productivity and personal traits because the over emphasis on personal traits may increase compliance, at the expense of both creativity and performance or unethical behavior. Therefore, this research aims to analyze the performance of rice farming in W est Kalimantan.

\section{METHODS}

The research was conducted within the three districts (Kubu Raya, Singkawang, and Sambas) that was the central location of food crop production and appropriate area for the rice development program in W est Kalimantan with interviews using 270 participants. The size of rice farmers met the criteria of multivariate analysis to estimate the appropriate indicators.

The inteview using an unstructured or semi-structured set of questions to get devote complete attention to every participant, listen actively and establish good result; helpful with difficult recruiting; elicit the candid responses during a private setting the personal and/ or professional topics of discussion; fewer distractions; faster and cheaper; and deeper insights (Turner, 2010; A lshenqeeti, 2014).

The findings of this study are structured base on farm performance assessment to meet sustainable farming. O ne way to classify on-thejob farmer behavior base on data performance assessments is to respond these following questions (i) what was done (such as productivity); (iii) H ow it was done (personal traits); (iii) W hat skill farmers had (proficiency). Productivity here can be measured in terms of specific performance accomplishments. While, personal traits such as motivation and willingness to join on cooperation may considered that can be translated into an achievement and how well an employee reportson assignment completion (productivity). Furthermore, proficiency, skill and knowledge plays an important role in work performance. W hen assessments address worker proficiency factors to help assure in overcoming deficiency that may be blocking future performance or growth. The data was analyzed using descriptive table to describe how the farming was done and the farmers skill. The model is based on the assumption of variablereturns to scale (VRS) and decision-making unit (DMU) in optimal condition. C riteria for efficiency of technical efficiency of ricefarming in Indonesia is above $70 \%$ (Kusnadi, Tinaprilla, Susilowati, \& Purwoto, 2011); (M urniati, Mulyo, Irham, \& H artono, 2014); (Suharyanto, Darwanto, \& W idodo, 2015).

\section{RESULTS DAN DISCUSSIONS}

$D$ ata on socio-demographic profile of the rice farmers were collected in terms of age, religion, ethnic, marriageable age, family members, and family expenses (Table 1). Based on the ages, majority of rice farmers is over forty years old and followed by over 30-40 year olds and over 20-30 year olds. The biggest proportion of population concerned in agriculture has faced a great challenge since most of youth as next generation doesn't intend in agriculture. The large mass of farmers still found in farming corroborates the justification for the study and in line with (Lasmini, N urmalina, \& Rifin, 2016) and (Khanal, Koirala, \& Regmi 2016); this can be not a good index to improved productivity as a result of farmers' productivity is deemed to decrease as they age. This makes it almost impossible for farmers in most developing countries to retire from active agricultural service and thus requires an inquiry into the effects of ageing on their agricultural activities as this has rural-urban migration and disenchantment of the younger generations from farming (Fasina, 2013). M inistry of A griculture (2007) additionally declared that agriculture sector doesn't offer an attractive incentive because of the relatively low output prices, expensive of input prices, and the narrow of land tenure.

On religion aspect, $97.41 \%$ farmersare M uslim. This find- 
ing was in line with majority population's faith in West Kalimantan as M uslim (59.52\%). According to Statistics Indonesia (BPS, 2015), 57.41\% farmers are M elayu ethnic because the center of paddy farming are within the coastal area that are usually dominated by this ethnic and solely small amount of farmers are M adura ethnic. M eanwhile, considering marriageable ages, farmer usually had married over 11 to 22 years (45.93\%) and over 22 to 33 years $(47.41 \%)$. The fact that the majority of the respondents is married over 11 years in line with their age that mostly over 40 years and will imply that couples are engaged in cooperative efforts in farming activities or operation. Their wives can so bea source of support for them even in their old age (Fasina, 2013).

Regarding members of the family, most of the farmer has more than equal to 2 to 4 of relations $(71.85 \%)$. Thisfinding was in line with (D eptan, 2007) and it indicated that farmers have started to pay attention to the quality of life for family members. The impact on farming indicated that there have been labor shortage within the family that further led to a rise in labor from outside the family and mechanization. For information on expense of household farmers were collected to explain the proportion of food expenses and non-food expenses. It had been found that $72.59 \%$ of rice farmers had spent on food but Rp.1, 500,000.00/ month, because the nonfood spending has reached 80 th. The most of ricegrown has spent on food is slightly under the non food goods indicated that the amount of social welfare is slightly increased and they want to change the level of life. (Deptan, 2007) verified that the spending on non-food goods are typically more popular within the aspects of health and education for their children to induce better occupation outside the agricultural sector within the future and based on a national survey of rice consumption tends to decrease for farmers household too.

M eanwhile, personal trait and proficiency-skill knowledge of rice farmers considered in the study included educational attainment, farm experiences, type of irrigation, member in farmers group, type of seed, sources of seed, family income, and working time as presented in Table 2 .

\section{TABE1 SUODFMOPAPHCCFABAGESTISSFIIERCEFAPMES}

\begin{tabular}{|c|c|c|}
\hline Sriochnegapicdaataitis & Feq & $(\%)$ \\
\hline \multicolumn{3}{|l|}{ Age } \\
\hline$>20$-30yeas & 3 & 111 \\
\hline$>30-40$ yeas & 59 & 278 \\
\hline$>40$ yeas & 208 & 77.04 \\
\hline \multicolumn{3}{|l|}{ Religan } \\
\hline Isam & 263 & 97.47 \\
\hline Chistiarity & 3 & 111 \\
\hline Cathdic & 4 & 148 \\
\hline \multicolumn{3}{|l|}{ Etriaty. } \\
\hline Bgis & 41 & 15.19 \\
\hline Maju & 155 & 57.4 \\
\hline Jana & 56 & 2074 \\
\hline Madra & 9 & 333 \\
\hline Ohes & 9 & 333 \\
\hline \multicolumn{3}{|l|}{ Mariageddeags } \\
\hline$<11$ yeas & 3 & 111 \\
\hline$\geq 11-22$ yeas & 124 & 45.98 \\
\hline$>22-33$ years & 128 & 47.47 \\
\hline$>33-44$ years & 13 & 481 \\
\hline$>4$ years & 2 & 074 \\
\hline \multicolumn{3}{|l|}{ Fanilynentees } \\
\hline$<2$ & 50 & 1852 \\
\hline$\geq 2-4$ & 194 & 718 \\
\hline$>46$ & 27 & 7.78 \\
\hline$>6-8$ & 2 & 074 \\
\hline$>8$ & 3 & 111 \\
\hline \multicolumn{3}{|l|}{ Exensedmath } \\
\hline \multicolumn{3}{|l|}{ Food } \\
\hline$<$ ^p1,500,00000 & 196 & 7259 \\
\hline > Rp1,500,0000- Rp3,500,000.00 & $Q$ & 2296 \\
\hline > Rp3,500,00000- Rp5,00,,00.00 & 12 & 44 \\
\hline \multicolumn{3}{|l|}{ Nonfood } \\
\hline$<$ Ro1,500,00000 & 276 & $80 \infty$ \\
\hline > Rp1,500,0000- Rp3,500,000.00 & 52 & 19.26 \\
\hline$>$ Rp3,500,0000- R05,000,000.00 & 2 & 074 \\
\hline
\end{tabular}

In Table 2, the level of pupillage attainment of the rice farmers shown that the majority of the respondents had $3-6$ years $(52.59 \%)$ that mean they only finished or unfinished on elementary school education (Lasmini, Nurmalina, \& Rifin, 2016) This means that the levels of illiteracy among older rice farmers are higher as the majority of the farmers can neither read nor write. This had implication for farmers' use of agricultural information or technology adoption, market access, competitiveness, and the devel opment of the agricultural sector (H obbs, 2003); Livingston, Schonberger, \& Delaney, 2011; (Ferroni, \& Zhou, 2011); (Awotide, Diagne, $\&$ Amonona, 2012). (0 phanhdala, 2009) even expressed that the farmers' education isquantitatively important rolein the agricultural performance. W hile, concerning farm experience, $41.11 \%$ of rice farmers had over $12-24$ years that was indicated that farm performance have significant impact on the 


\section{TABE2 PEBOAL TRAT GFCEFAPMES}

\begin{tabular}{|c|c|c|}
\hline Pesond Tät & Feq & $\%$ \\
\hline \multicolumn{3}{|l|}{ Prpilagedtaimert } \\
\hline$<3$ yeas & 31 & $114 \varepsilon$ \\
\hline$\geq 3-6$ yeas & $14 \mathrm{E}$ & 525 \\
\hline$>6-9$ yeas & 64 & $23 \pi$ \\
\hline$>9-12 y e a r$ & 3 & 1111 \\
\hline$>12$ year & 3 & 111 \\
\hline \multicolumn{3}{|l|}{ Famepaieres } \\
\hline$<12$ year & 41 & 17.47 \\
\hline$\geq 12-24$ yas & 111 & 4111 \\
\hline$>24-36 y$ ears & 7 & 2630 \\
\hline$>3 x-48 y e a c$ & 31 & $114 \varepsilon$ \\
\hline$>48$ year & $\mathbb{I C}$ & $3 \pi$ \\
\hline \multicolumn{3}{|l|}{ Types of imigtion } \\
\hline Raiffer & $19=$ & $714 \varepsilon$ \\
\hline Imigtion & $\pi$ & 27.78 \\
\hline Tich & 2 & 074 \\
\hline \multicolumn{3}{|l|}{ Mentersinfatergap } \\
\hline Yes(suppot withtratas spayes ricethesha) & 2 & 926 \\
\hline Yes(sppotwithseed fetilizes pesticke) & $16=$ & 603 \\
\hline Yes(supptwithtraining & 31 & $114 \varepsilon$ \\
\hline $\mathrm{Nb}$ (motraining) & 45 & 166 \\
\hline $\mathrm{Nb}$ (roirfamation) & 6 & 222 \\
\hline \multicolumn{3}{|l|}{ Typesofsed } \\
\hline Inparal & 58 & 2748 \\
\hline Inpra2 & 36 & 1333 \\
\hline Inpaa3 & 54 & 2000 \\
\hline Chean & 81 & 300 \\
\hline Hybid & 41 & 15.19 \\
\hline \multicolumn{3}{|l|}{ Sarcesofsed } \\
\hline Coermert & 78 & 2889 \\
\hline Privete & 47 & 17.41 \\
\hline Oésonn & 26 & 963 \\
\hline Coernertandpinete & 64 & 2370 \\
\hline Coermertardorésour & 5 & 2031 \\
\hline \multirow{2}{*}{\multicolumn{3}{|c|}{$\begin{array}{l}\text { Fanilyintone } \\
\text { O-Fam }\end{array}$}} \\
\hline & & \\
\hline$<$ pp1,500,000œ & $\notin$ & 325 \\
\hline$>$ > Rp1,500,000, - $\mathrm{po} 3,500,000,00$ & 84 & 3111 \\
\hline$>\mathrm{Rp} 3,500,000, \infty-\mathrm{Rp5}, 000,0000$ & 51 & 1889 \\
\hline$>$ > R०5,œ, & 42 & 15.56 \\
\hline$>\mathrm{Rp} 7,000,000 \propto$ & 5 & 18 \\
\hline \multicolumn{3}{|l|}{ Ol-Fam } \\
\hline$<\mathrm{Ap1,500,000 \propto}$ & 31 & $78 T_{2}$ \\
\hline$>$ pp1,500,000, & 7 & $14 \&$ \\
\hline$>$ > $\mathrm{p} 3,500, \infty 0, \infty-\mathrm{R} 05, \infty, \infty 0 \propto$ & 3 & $6 x$ \\
\hline \multicolumn{3}{|l|}{ No-Fam } \\
\hline$<\mathrm{Pp} 1,500,000 \propto$ & $4 E$ & 483 \\
\hline 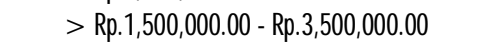 & $\mathbf{2}$ & 2366 \\
\hline$>\mathrm{Rp} 3,500,000,0-\mathrm{Rp} 5,000,000, \propto$ & 16 & 17.2 \\
\hline 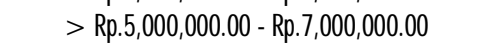 & $\varepsilon$ & $8 \propto$ \\
\hline$>\mathrm{Ro7}, 000,00 \propto$ & 2 & 215 \\
\hline
\end{tabular}

variation of output (Julius, \& Chukwumah, 2014).

On types of irrigation, most of rice farmers in West Kalimantan used rainfed and followed by irrigation (27.78\%). The use of rainfed is because of the constraints of funds allocated for irrigation by local governments. H owever, in each rainfed and irrigated agriculture, farm yields and financial returns are also ruled briefly to medium-term by alternative factors, including: the quality of soil and land resources on the farm; the systems of land use and rotations that best suit the land resource and conjointly the climate; and the way a lot of money is invested with in optimising economic returns and adopting improved farming practices to overcome constraints on yield. This finding was in line with (C assman, 2016); to identify the foremost promising solutions requires robust assessment of crop yield trajectories, food production capacity at local to global scales, the role of irrigated agriculture, and water use efficiency is effective; the policies and regulations are required to make sure that water resources aren't being depleted or degraded.

R egarding members in farmers group, $60.37 \%$ rice farmers belong to farmers groups for seed, fertilizers, pesticide aid and $9.26 \%$ for tractors, sprayers, rice thresher aids from the government. The link between social capital and collective action among farmers has been well documented in the literature; highlighted the importance of collective action specific to rising small-holder ben efits inside the value chain and enabling them to comprehend market access and bargaining power (Ramdwar, Valerie, \& G anpat, 2014).

C onsidering types of seed, C iherang is more widely used than the Inpara 1, Inpara 3, hybrid, and Inpara 2. In direct seeding, seeds are sown directly within the field. Whereas in transplanting, the seedlings are at the start raised in seedbeds before they are planted within the field. Rice farmers habitually select the appropriate seed base on locality, kind of soil, rice ecosystem, and additionally the availability of inputs and labor. H owever, a number of the things that are done for many years by rice farmers in West Kalimantan to createrice plants grow haveunfortunately reduced their natural potential. This new system of rice inten sification changes these ancient practices to bring out of the rice plant vital prospects for increasing production. The yields that will be achieved by every individual farmer will rely on several things: in the care of source of seed also became one of a way to make sure the rice productivity is guaranteed. This finding proved that source of seed from the government was most preferred by ricefarmers (28.89\%) because the qualityis more secure and reliable. 
O ne of the biggest constraints of the consecutive adoption of improved varieties is that the provision of seed. M eanwhile, access to seed may be a necessary condition for improved seed adoption and also the adoption of improved seed is a crucial component of agricultural productivity, food security and sustainable economic process. Therefore, the persistence of lack of access to certified improved rice seed can jeopardize the efforts to attain self-reliance in rice production, and also the dependence on import would still expose the state to international shocks.

Knowl edge of existing varieties, perception regarding the attributes of improved varieties, household wealth and accessibility of the active labor force are major determinants for adoption of improved technologies. The adoption of improved agricultural technologies has a significant positive impact on farmers' integration into output market and also the findings are consistent that suggesting the strength of the results. This confirms the potential direct role of technology adoption on market participation among rural households, as higher productivity from improved technology interprets into higher output market integration (Asfaw, Shiferaw, Simtowe, \& Hagos, 2011).

Regarding with the family income, off-farm income generates more revenue than nonfarm and onfarm. Farm households rely upon income from each off-farm and nonfarm activities. Consequently, for several farm households, economic decisions (including technology adoption and different production decisions) are probable to be formed by the allocation of time among such activities. Whereas time allocation decisions are typically not measured directly, we tend to observe the outcomes of such decisions, like offfarm and nonfarm income. (Fernandez-Cornejo, 2007) found that a farm operator's off-farm employment and off-farm income vary reciprocally with the scale of the farm. 0 perators of smaller farm operations, improvetheir economic performance by compensating for the scale disadvantages of their farm business with more offfarm involvement. 0 ff-farm work reduces farm-level technical efficiency, however, can increase household-level technical efficiency. Adoption of agricultural innovations that save management time is expounded to higher off-farm income.

This finding also proved that the household income of rice grower has not, however, met all the needs of households in order that they look for other sources of income outside of farming, such as labor, fishing, merchants, transport suppliers, industrial household or alternative work that's unskilled job (Nasir, M ulyana, \& Yunita, 2015). Those findings have been strengthened by the characteristics of land tenure, productivity, and the revenue of rice farmers per season that are presented in table 3.

\section{TABE3 LANDIENFE, PROUTIMTY, REVNEGFRCFAMMG}

\begin{tabular}{|c|c|c|}
\hline ladTane(r) & Fig. & $\%$ \\
\hline$<0.2$ & $\mathrm{c}$ & $33=$ \\
\hline $0.55-<0.5 C$ & $1 \overline{1}$ & 63 \\
\hline $0.50-<1 \propto$ & 6 & 2481 \\
\hline $100-<12$ & 9 & 333 \\
\hline $125-<15 C$ & $\epsilon$ & 22 \\
\hline $150-<1 \pi$ & $\chi$ & 7.41 \\
\hline $1 \pi-<2 \propto$ & $\mathrm{C}$ & $0 \propto 0$ \\
\hline $200-<2 Z$ & $4 z$ & 15.56 \\
\hline$\geq 2.25$ & $1 \mathrm{C}$ & 7.04 \\
\hline \multicolumn{3}{|l|}{ Rodutivity(Kg/-a) } \\
\hline$<500 \mathrm{~kg} / \mathrm{hE}$ & 4 & $14 \varepsilon$ \\
\hline $500-<1,50$ & $4 i$ & 17.41 \\
\hline $1,250-<2,000$ & 40 & 1481 \\
\hline $2,000-<2,50$ & 40 & 1481 \\
\hline $2,750-<3,500$ & 20 & 7.41 \\
\hline $3,500-<4,50$ & 40 & 1481 \\
\hline $4,250-<5,000$ & 3 & 111 \\
\hline $5,000-<5,50$ & 13 & 481 \\
\hline $5,50-<6,500$ & $\mathrm{c}$ & $33=$ \\
\hline$\geq 6,500 \mathrm{~kg} / \mathrm{ha}$ & 54 & $20 \propto$ \\
\hline \multicolumn{3}{|l|}{ Peane $(\mathrm{Rd} / \mathrm{B})$} \\
\hline$<1,500,00$ & $C$ & $\mathrm{C}$ \\
\hline $1,500,00-<3,00, \infty 0$ & 1 & 481 \\
\hline $3,00,000-<4,500, \infty 00$ & 16 & 593 \\
\hline $4,500,000-<6,00,00 \times$ & $\chi$ & 7.41 \\
\hline $6,00, \infty 00-<7,500, \infty 0$ & 24 & $8 \notin$ \\
\hline $7,500,000-<9,000,00$ & $2 i$ & $10 \propto$ \\
\hline $9,00,000-<10,50,00$ & $\Sigma$ & 85 \\
\hline $10,500, \infty 00-<12,00,000$ & $\chi$ & 7.47 \\
\hline $12,00, \infty 00-<13,500,000$ & $1 \overline{1}$ & 63 \\
\hline $13,500,000-<15,000,000$ & $1 \overline{1}$ & 63 \\
\hline$\geq 15,000,000$ & 93 & 34,4 \\
\hline
\end{tabular}

On land tenure, mostly rice grower only had 0.25 -less than 1.25 ha (58.14\%) and this finding proved that the land owned is limited not only in Java but also outside Java, particularlyin West Kalimantan (Table 3). These conditions had an impact on the society in the region. Land ownership is not only important for agriculture, but al so for varying needs in society. The land serves as a productive asset and commodity that could be traded. Theshrinkage problems of productive land for farming generally due to rampant conversion of agricultural land to non-agricultural (Suhartanto, 2009). (W inarso, 2012) also stated that the shrinkage of land tenure occurs in all types of rice field land because of some reasons. First, the transaction of sale and buy of land; second, the distribution of inheritance or grants which had re- 
sulted in the marginalization of land ownership and small farmers tend to sell their land because of the income earned from the land does not meet the needs of the household; third, land conversion.

While, on rice productivity, only $20 \%$ of ricegrower could make over 6.5 ton/ ha and mostly rice farmers ( $80 \%$ ) got less than it. Land tenure were proved have a positive significant relationship with the value of rice production, rice productivity, and the technical efficiency (Koirala, Mishra, \& M ohanty, 2014); (Shaikh, H ongbing, Khan, \& A hmed, 2016). (Koirala, Mishra, \& Mohanty,2014) also stated that yield improvement is governed mainlyin two ways; either shifting the yield frontier or by developing and promoting yieldenhancing technologies. Improving rice productivity can give to higher yield and in reducing poverty, especially in rural areas, increased productivity may al so help in increasing the income and food security of small farmers, who depend on rice production for a living. Land tenure would also affect the household income levels and show that the Gini index in somevillages had great value(C ervantes-G od oy, \& D ewbre, 2010). The relationship between farm income and land tenure levels indicates that income distribution was affected by the strata of land ownership, the land owned will increase theincome of households. Thus, thefarmershouseholds that have a large of land tenure, have a greater range of the nonagricultural sources (W inarso, 2012). Thisfinding was proved by the ownership of highest income, $34.44 \%$ of rice farmers had more than equal to 2.25 ha of land tenure.

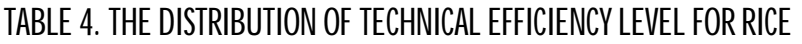 FAPMNG}

\begin{tabular}{|c|c|c|}
\hline \multirow[t]{2}{*}{ Thricd Eidery } & \multicolumn{2}{|c|}{ ReFanir } \\
\hline & Feq & $(\%$ \\
\hline $0 \%-20 \%$ & $\mathrm{C}$ & $\mathrm{C}$ \\
\hline$>20 \%$ - $30 \%$ & 1 & 0.31 \\
\hline$>30 \%-40 \%$ & 3 & 111 \\
\hline$>40 \%-50 \%$ & 2 & 2296 \\
\hline$>50 \%-60 \%$ & 75 & 27.78 \\
\hline$>60 \%-70 \% /$ & 8 & 3037 \\
\hline$>70 \%$ & 47 & 17.41 \\
\hline Alagge & & $0.43 C$ \\
\hline Neximer & & $0,7 \pi$ \\
\hline Mrimem & & 0,255 \\
\hline
\end{tabular}

Furthermore, the distribution of technical efficiency for rice farmers farming are presented in table 4 . Technical efficiency is concerned with producing goods and services with the optimal combination of inputs to produce maximum output for the minimum cost. To be technically efficient means the economy must be produced on its production possibility frontier. Technical efficiency is also closely related to the concept of productive Efficiency. This technical efficiency of rice farming was measured to assess the achievement of the target application of technology to increase production and productivity or technical efficiency can explain the adoption rate of technology.

Table 4 showed thedistribution of technical potency level for rice farmers farming shown that only $17.41 \%$ rice grower who are able to accomplish sufficient; while over $60-70 \%$ technical efficiency achieved by $30.37 \%$ of rice farmers and the others less than the accomplishment of this technical efficiency. So, only a few of rice farmers were able to attain sufficient on farming in West Kalimantan. Average accomplishment of technical efficiency was $43.9 \%$, whereas minimum accomplishment of technical efficiency was $25.5 \%$ and $77.9 \%$ of maximum achievement of technical efficiency. This finding was signaled for the government to accelerate the adoption of technology for rice grower, even though the appliance of technological innovation is determined by the financial ability or the rice farmers household that wereoccurringon all domestic food crop farmers al ready (Aji, Satria, \& H ariono, 2014); (Sumarno, H arianto, \& Kusnadi, 2015).

Future improvements may be expected from continued innovations in both agronomic practices and genetic improvement, although current seed company business models are in question given rush to merge for all major seed firms, and appropriate business models have yet to be developed to require full advantage of farmer-reported information on crop management, high resolution spatial information on soils and climate, as well as advances in computing power, remote sensing, communication technologies, and crop simulation models (C assman, 2016).

The characteristics that ensure an innovation's rate of adoption are: relative advantage; compatibility; complexity; trialability; and observability to those people among the social structure (Rogers, 2003). (Lasmini, N urmalina, \& Rifin, 2016) stated that the benefits of technology adoption can be done by presenting the figure of the progressive farmers who have higher technical efficiency characteristics than other farmers, grasp more regarding rice farming, respond positively and had extension recommendation adopting best of rice farming. Therefore policies leading to raising the educational level of the farmer, increasing their technical efficiency, guaranteeing greater access to microfinance, crop specific regional focusing and strengthening the extension services through a lot of intensive on-farm demonstrations might be useful to increasing technical efficiency and adoption of technology. 
(Galero, \& Tiongco, 2014) in their research also gavesome recommendation related empirical findings, an urgent to extend and sustain investments in agriculture, particularly on research and development, infrastructures and smallholder productivity. Through these, there can below cost irrigation and resourceefficient technologies, like integrated soil fertility management using the combination of each fertilizer and manure or compost, particularly for the rainfed areas. There's additionally a desire to enhance and depend upon human resource capability through education, coaching and extension to boost investments further, the government should encourage non-public sector participation, particularly wherever market failure is clear. N ext, the govt ought to improve access to the main agricultural inputs, such as fertilizers and seeds. These should be at a low price so that the farmers will afford them and for the distributors to urge back their prices and still earn profits. Lastly, the govt ought to overcome institutional contraints. The government should also safeguard the right of the farmers particularly to their land.

Furthermore, relating to risks of rice farming are given in table 5. Assessing risk at the farming levels helps rice farmers to understand risk, create better decisions and build risk mitigation scenarios. Risk assessments also cause accurate plans that are less likely to steer to budget overruns or delays. Cost commitments, revenue pipelines, and profit forecasts are going to be accurately stated for each level of risk. The sensitivity of the forecasts are going to be better understood. When informed by the risk assessment, the whole farming are going to be more profitable.

Table 5 demonstrated the risk assessment of rice farming used the standards of coefficient of variance. If the coefficient of variance value is over 0.5 then the rice farming risks borne by rice farmers was at the lower limit value, whereas if the constant of variance worth less than equal to 0.5 then the rice farmers continuously take the profit or break even at the lower limit value. These findings tested that the risk of production, prices, and financial gain on rice farming were low or the coefficient of variance value were less than 0.5 so rice farmers will take profit. These findings were contrary to the findings of (Suharyanto, Darwanto, \& W idodo, 2015) that higher risk was occured in rice farming and it had been influenced principally byland tenure, organic fertilizers, and pesticides. Less of rice farmers able to attain the technical efficiency, productivity, profit and income in farming or to avoid risks as their expected as a result of several factors, which might be controlled (internal) or that can't be controlled (external), and since of the intensity of the input and output price.

\section{TABE5 RSKANAYSSOFRCFARMNG}

\begin{tabular}{|c|c|c|}
\hline & Desiptia & Vete \\
\hline \multirow[t]{4}{*}{ Podution } & Aerage & $3,314.519$ \\
\hline & Standaddaritior & $12629 \pi$ \\
\hline & Loner limit & $3,289.9510$ \\
\hline & Thecoefficet of verianc & 0.004000 \\
\hline \multirow[t]{4}{*}{ Pice } & Aerage & 4,597 \\
\hline & Standaddaritior & 1337824 \\
\hline & Lonerlinit & 4594.324 \\
\hline & Thecoefficet ofveriank & 0.000291 \\
\hline \multirow[t]{4}{*}{ Inrome } & Aerage & $13,795,710$ \\
\hline & Sandarddaritior & 84,16314630 \\
\hline & Loner linit & 12,107,4AB, 7 \\
\hline & Thecofficiet ofverianc & 0.061115 \\
\hline
\end{tabular}

Thus, some methods can betaken that were based on the outline and abstract of empirical results. First, Ex-ante strategy that's the strategy beforethe shock happens. It's designed to anticipate when the shocks are coming so the farm isn't within the prone position. Second, interactive strategy, the strategy is taken at the time of shocks by being relocated the resource so impact risks are often reduced. Third, ex-post strategy that's strategy when the shock happens to reduce its impact. W hile, (Roy, C han, \& Xenarios, 2016) in their findings suggest that pluralistic (the government and non-government) agricultural consultative services can serve as an engine of transition in rice production, sustainability during which a multi-year coming up with and strategy formulation is crucial besides investment in the modernization of extension services.

The sustainable farm Techniques also consistent with (Flynn, 2015), policy makers would like information on the situation of rice production and on improved technologies that are obtainable for sustainable intensification of rice production in order to formulate acceptable policies for supporting rice production. On the opposite hand, global rice production is endeavor issues like international global climate change and also the insufficiency of water, land and energy resources. The issues and opportunities for a sustainable increase of rice production differ from one rice ecosystem to a distinct due to the variations in environmental and socioeconomic conditions, degrees of intensification.

There are existing improved and promising technologies that may be accustomed boost farmers' production and to increase their incomes, whereas guaranteeing environmental conservation, i.e. Genetic improvement, minimizing the effects of the scarcity of water, land, and labor resources, minimum and/ or zero tillage, land levelling victimization laser beam, direct seeding in lowland rice production, motility and intermittent irrigation, aerobic rice or irrigated upland rice, 
and innovation in a traditional trade (Flynn, 2015). (0 xfam, 2014) ensured that smallholders and agroecological farmers are concerned in shaping policies and investments in agriculture. This requires puttingin or strengthening multi-stakeholder platforms at native, national, and regional levels that embrace small-scale food producers. Second, develop adequate public incentives to push agroecological practices; make sure that the proper policies are in place to support agroecological approaches; and makesure that strong farmerled, bottom-up knowledge and research systems are in place.

\section{CONCLUSIONS}

This research found that socio-demographic characteristics of the rice farmers were over 40 years old; M uslim; M elayu ethnic; had married for over 11 years; has more than equal to 2 to 4 of family members; and slightly spend less on food than thenonfood goods. M eanwhile, personal trait and proficiency-skill knowledge of rice farmers proved that pupillage attainment had 3 to 6 years; used rainfed; widely used Ciherangseeds; and off-farm incomegenerates more revenue than non-farm or on-farm. This finding was proved by the ownership of highest income, $34.44 \%$ of rice farmers had more than equal to 2.25 ha of land tenure. The distribution of technical efficiency showed that only $17.41 \%$ rice grower who are able to achieve sufficient; while over $60-70 \%$ technical efficiency achieved by $30.37 \%$ of rice farmers. H owever, the risk of production, prices, and income were low or less than 0.5 so that rice farmers can take a profit.

\section{REFERENCES}

Aji, A. A., Satria, A., \& Hariono, B. (2014). Strategi Pengembangan Agribisnis Komoditas Padi Dalam Meningkatkan Ketahanan Pangan Kabupaten Jember. Jurnal Manajemen $\&$ Agribisnis, 11(1), 60-67.

Alshenqeeti, H. (2014). Interviewing as a Data Collection Method: A Critical Review. English Linguistics Research, 3(1), 39-45.

Asfaw, S., Shiferaw, B., Simtowe, F., \& Hagos, M. (2011). Agricultural Technology Adoption, Seed Access Constraints And Commercialization in Ethiopia. Journal of Development and Agricultural Economics, 3(9), 436-447.

Awotide, B. A., Diagne, A., \& Amonona, B. T. (2012). Impact of Improved Agricultural Technology Adoption on Sustainable Rice Productivity and Rural Farmers' Welfare in Nigeria: A Local Average Treatment Effect (LATE) Technique. African Economic Conference October 30 - November 2, 2012 (pp. 1-23). Kigali, Rwanda: AFDB.

Billikopf, G. (2014). Labor Management in Agriculture: Cultivating Personal Productivity. California, USA: University of California.

BPS, C. B. (2015). Statistics Population of West Kalimantan Province. Pontianak: Central Bureau of Statistics (BPS).

Cassman, K. G. (2016). Long-Term Tranjectories: Crop Yields, farm lands, and irrigated agriculture. Kansas City Federal Reserve Symposium, Agriculture's Water Economy, July 11-12, 2016. Kansas: Kansas City Federal Reserve.
Cervantes-Godoy, D., \& Dewbre, J. (2010). Economic Importance of Agriculture for Sustainable Development and Poverty Reduction: Findings from a Case Studi of Indonesia. Paris: OECD.

Deptan. (2007). Analisis Profil Petani dan Pertanian di Indonesia. Bogor: Pusat Analisis Sosisal Ekonomi dan Kebijakan Pertanian, Badan Penelitian dan Pengembangan Pertanian.

Elferink, E., Kuneman, G., Visser, A., \& Van Der Wal, E. (2012). Sustainability Performance Assessment of Farming Practices: Guidelines for developers of quantitative monitoring tools. Culemborg, Netherlands: Centre for Agriculture and Environment (CLM).

Fasina, Oluwatosin Oluwasegun. (2013). Famers Perception of the effect of aging on their agricultural activities in Ondo State, Nigeria. Venets: The Belogradchik Journal for Local History, Cultural Heritage and Folk Studies, 4(3), 371-387.

Fernandez-Cornejo, J. (2007). Off-Farm Income, Technology Adoption, and Farm Economic Performance, Economic Reseach Report Number 36. USA: United States Department of Agriculture (USDA).

Ferroni, M., \& Zhou, Y. (2011). Review of Agricultural Extension in India. Switzerland: Syngenta Foundation for Sustainable Agriculture.

Flynn, D. (2015). Sustainable Rice Culture in Asia. World Journal of Social Science, 2(2), 14-26.

Galero, S., So, S., \& Tiongco, M. (2014). Food Security versus Rice SelfSufficiency: Policy Lessons from the Philippines. DLSU Research Congress 2014, M arch 6-8, 2014 (pp. 1-7). Manila: De La Salle University.

Hobbs, J. (2003). Incentives for the adoption of Good Agricultural Practices: Background paper for the FAO Expert Consultation on a Good Agricultural Practice Approach. Rome, Italy: FAO.

Julius, A., \& Chukwumah, A. F. (2014). Socio-economic Determinants of Small-Scale Rice Farmer's Output in Abuja, Nigeria. Asian Journal of Rural Developmnet, 4(1), 16-24.

Khanal, A. R., Koirala, K., \& Regmi, M. (2016). Do Financial Constraints Affect Production Efficiency in Drought Prone Areas? A Case from Indonesian Rice Growers. Southern Agricultural Economics Association's 2016 Annual M eeting, San Antonio, February 6-9, 2016 (pp. 1-23). Texas: Southern Agricultural Economics Association.

Koirala, K. H., Mishra, A. K., \& M ohanty, S. (2014). Determinants of Rice Productivity and Technical Efficiency in the Philippines. Southern Agricultural Economics Association (SAEA) Annual Meeting, February 14, 2014 (pp. 1-15). Dallas: Southern Agricultural Economics Association (SAEA).

Kusnadi, N., Tinaprilla, N., Susilowati, S. H., \& Purwoto, A. (2011). Analisis Efisiensi Usahatani Padi di Beberapa Sentra Produksi Padi di Indonesia. Jurnal Agro Ekonomi, 2(1), 25-48.

Lasmini, F., Nurmalina, R., \& Rifin, A. (2016). Efisiensi Teknis Usahatani Padi Petani Peserta dan Petani Non Peserta Program SL-PTT di Kabupaten Sukabumi. Jurnal Manajemen \& Agribisnis, 13(1), 50-58.

Livingston, G., Schonberger, S., \& Delaney, S. (2011). Sub-Saharan Africa: The state of smallholders in agriculture. IFAD Conference on New Directions for Smallholder Agriculture (pp. 1-32). Rome, Italy: International Fund for Agricultural Development (IFAD).

Mahbubi, A. (2013). Model Dinamis Supply Chain Berkelanjutan dalam Upaya Ketahanan Pangan Nasional. Jurnal Manajemen \& Agribisnis, 10(2), 81-89.

Ministry of Agriculture. (2007). Analisis Profil Petani dan Pertanian di Indonesia. Bogor: Pusat Analisis Sosisal Ekonomi dan Kebijakan Pertanian, Badan Penelitian dan Pengembangan Pertanian.

Murniati, K., Mulyo, J. H., Irham, \& Hartono, S. (2014). Efisiensi Teknis Usaha Tani Padi Organik Lahan Sawah Tadah Hujan di Kabupaten Tanggamus Provinsi Lampung. Jurnal Penelitian Pertanian Terapan, 
14(1), 31-38.

Nasir, Zahri, I., Mulyana, A., \& Yunita. (2015). Pola Usaha dan Pendapatan Rumah Tangga Petani pada Berbagai Tipologi Lahan Rawa Lebak. Jurnal Manajemen \& Agribisnis, 12(3), 183-193.

Ophanhdala, P. (2009). Farmer education and rice production in Lao PDR. Journal of International Cooperation Studies, 16(3), 105-121.

OXFAM. (2014). Bulding A New Agricultural Future: Supporting agroecology for people and the planet. Oxford: www.oxfam.org.

Ramdwar, M. N., Valerie, A. S., \& Ganpat, W. G. (2014). A Focus Group aprroach to exploration of dynamic of farmers' group in Trinidad, West Indies. Journal of Agricultural Extension and Rural Development, 6(9), 288-297.

Rogers, E. M. (2003). Diffusion of Innovations, 5th Edition. New York: Free Press.

Roy, R., Chan, N. W., \& Xenarios, S. (2016). Sustainability of Rice Production Systems: An Empirical Evaluation To Improve Policy. Environment, Development and Sustainability, 18(1), 257-278.

Shaikh, S. A., Hongbing, O., Khan, K., \& Ahmed, M. (2016). Determinants of Rice Productivity: An analysis of Jaffarabad District-Balochistan (Pakistan). European Scientific, 12(13), 41-50.

Suhartanto. (2009). Ketersediaan Lahan Pertanian Pangan Secara Berkelanjutan Untuk M enjaga Ketahanan. Jakarta: Direktorat Jenderal Pengelolaan Lahan dan Air-Departemen Pertanian.

Suharyanto, Mulyo, J. H., Darwanto, D. H., \& Widodo, S. (2015). Analisis Produksi dan Efisiensi Pengelolaan Tanaman Terpadu Padi Sawah di Propinsi Bali. Penelitian Tanaman Pertanian Pangan, 34(2), 131-144.

Suharyanto, Rinaldy, J., \& Arya, N. N. (2015). Analisis Risiko Produksi Usahatani Padi Sawah di Propinsi Bali. AGRARIS: Journal of Agribusiness and Rural Development Research, 1(2), 70-77.

Sumarno, J., Harianto, \& Kusnadi, N. (2015). Peningkatan Produksi Dan Efisiensi Jagung Melalui Penerapan Pengelolaan Tanaman Terpadu (PTT) di Gorontalo. Jurnal Manajemen \& Agribisnis, 12(2), 79-91.

Turner, D. W. (2010). Qualitative Interview Design: A Practical Guide for Novice Investigators. The Qualitative Report, 15(3) , 754-760.

Winarso, B. (2012). Dinamika Pola Penguasaan Lahan Sawah di Wilayah Pedesaan di Indonesia. Jurnal Penelitian Pertanian Terapan, 12(3), 137149. 